\title{
OPTIMALISASI PEMILAHAN SAMPAH ORGANIK DAN UNORGANIK DALAM SKALA RUMAH TANGGA DI DESA CANDIWATU
}

\author{
Siti Nuurlaily Rukmana ${ }^{1)}$, Anak Agung Sagung Alit Widyastuty ${ }^{2)}$, Annisa Budhiyani T ${ }^{3)}$ \\ ${ }^{2}$ Fakultas Teknik Sipil dan Perencanaan, Universitas PGRI Adi Buana Surabaya \\ email: nuurlaily_rukmana@unipasby.ac.id, sagungalit@unipasby.ac.id, annisatb@unipasby.ac.id,
}

\begin{abstract}
Abstrak
Desa Candiwatu digolongkan kawasan pedesaan di Kecamatan Pacet Kabupaten Mojokerto. permasalahan di kawasan pedesaan termasuk Desa Candiwatu yaitu pada pola pikir hidup masyarakatnya dalam menghadapi permasalahan lingkungan. Persoalan yang dihadapi oleh masyarakat Desa Candiwatu salah satunya adalah persampahan. Solusi yang ditawarkan oleh tim pelaksana pengabdian kepada masyarakat adalah sosialisasi pentingnya proses pemilahan sampah organic-unorganik serta pemberian sampah berdasarkan jenis sampahnya. Pelaksanaan pengabdian masyarakat ini bertujuan untuk mengetahui presentase pengetahuan masyarakat tentang optimalisasi sampah organic-unorganik skala rumah tangga. Metode pelaksanaan adalah sosialisasi dan pemberian tempat sampah sebagai alat untuk proses pemilahan sampah. Hasil dari sosialisasi dapat diketahui bahwa pengetahuan masyarakat dalam pemilahan sampah mengalami kenaikan yang awalnya 25,6 \% menjadi 65,6\%.
\end{abstract}

Kata kunci: organic, Pemilahan sampah,unorganik

\begin{abstract}
Candiwatu village categorized as rural area at Pacet subdistrict Mojokerto Regency that has issues such as their mindset of life towards environmental problems. One particular matter was waste management. The service execution team gave solution such as advocation to the community in the consequential value in managing waste as organic and inorganic based on the waste type. The purpose of the service programme implementation was to gauge the percentage of the community knowledge about organic-inorganic waste optimalization in household scale. Methods that are utilized was socialization and giving the tools such as customized garbage disposal as a way to manage waste manually. The results of the programme was the community knowledge in managing waste went up from $25,6 \%$ to $65,6 \%$.
\end{abstract}

Keywords: organic, waste management, unorganik

\section{PENDAHULUAN}

Desa Candiwatu Kecamatan Pacet Kabupaten Mojokerto digolongkan sebagai kawasan pedesaan. Seringkali permasalahan di kawasan pedesaan termasuk Desa Candiwatu yaitu pada pola pikir hidup masyarakatnya dalam menghadapi permasalahan lingkungan. Persoalan yang dihadapi oleh masyarakat Desa Candiwatu salah satunya adalah persampahan. Kondisi yang ada saat ini yaitu masyarakat belum melakukan pemilahan sampah. Artinya sisa pembuangan rumah tangga langsung dibuang tempat sampah, bahkan ada yang dikubur dan dibuang di sungai. Ketidak adaan TPST (Tempat Pembuangan Sampah Sementara) mendukung pola hidup masyarakat untuk membuang sampah di bukan tempatnya.

Kebiasaan masyarakat dalam membuang sampah yaitu dengan cara menimbun sampah, dibakar, bahkan ada yang membuang sebagian sampahnya ke sungai. Hal ini tentunya disebabkan karena minimnya pengetahuan masyarakat dalam pengolahan sampah .Fenomena ini selaras dengan (Krisnani, Humaedi, Ferdryansyah, \& Asiah, 
Dessy Hasanah Siti Asiah, Gigin G Kamil Basar, Sri Sulastri, 2017); (Pambudi \& Sudaryantiningsih, 2017) bahwa mayoritas pola pikir masyarakat menganggap sampah adalah sumber dan benda yang tidak memiliki manfaat lagi. Mereka belum memahami bahwa sampah tersebut bila dikelola dengan baik dapat memberikan potensi dan tentunya menguntungkan bagi masyaraktnya sendiri. Pemanfaatan sampah dimulai pada proses pemilahan sampah. Proses ini sering disebut sebagai proses penanganan sejak dini.

Pemilahan sampah merupakan upaya pemisahan sampah yang dilakukan pada tahap awal. Proses pemilahan sampah ini dilakukan berdasarkan jenis sampahnya. Untuk menjadikan sampah yang efektif maka dilakukan dengan berbagai tahap yaitu dimulai pewadahan, pengumpulanan, pengangkutan, pengolahan, hingga pembuangan, melalui pengendalian pengelolaan organisasi yang berwawasan lingkungan (Utami, Indrasti, \& Dharmawan, 2008).

Selain itu, Proses pemilahan sampah dapat dilakukan dengan cara melibatkan masyarakat khususnya dalam perilaku (Andina, 2019), seperti dimulai dari sarana kesehatan, pendidikan, sarana ekonomi (pasar) dan lainnya. Guna memudahkan pemilahan sampah, maka diberikan cat yang berbeda di masing-masing tempat sampah (Gambar 1)

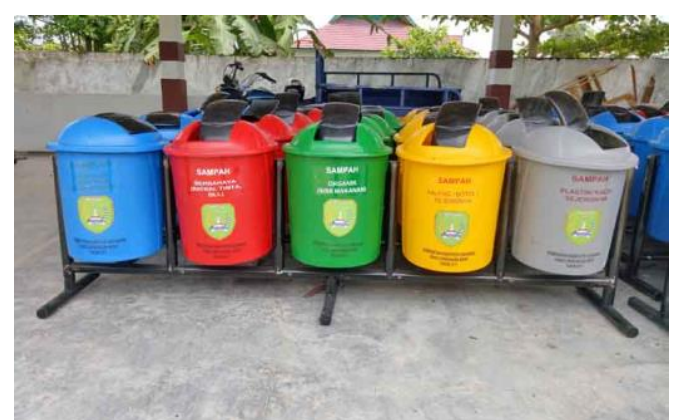

Gambar 1 Jenis Tempat Sampah Berdasarkan Tempatnya

Pemilahan sampah yang efektif harus diberikan reward. terkait dengan proses pemilahan sampah serta diikuti dengan pemberian tempat sampah. Metode ini dinilai langkah awal dalam peningkatan wawasan masyarakat (Latifatul, A, A, \& Nur, 2018). Saat ini dimulai dari berbagai kampung telah menerapkan proses pemilahan sampah melalui bank sampah (Sanusi et al., 2016)

\section{METODE PELAKSANAAN}

Pelaksanaan Pengabdian Pada Masyarakat (PPM) ini berlokasi di Desa Candiwatu Kecamatan Pacet Kabupaten Mojokerto (Gambar 2). Sasaran kegiatan ini adalah kelompok karang taruna dan aparatur Desa yang dilaksanakan di kantor Desa. Metode pendekatan yang dilakukan untuk solusi permasalahan dengan mitra yaitu sosialisasi

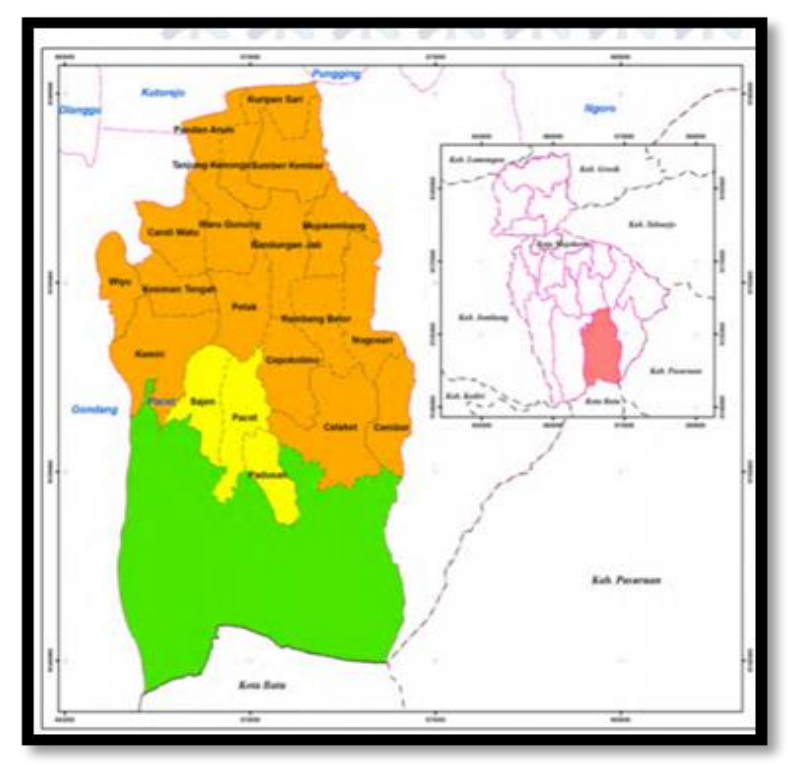

Gambar 2 Peta Wilayah Studi

Adapun prosedur pelaksanaan pengabdian ini yaitu:

a. Observasi Lapangan

Pelaksanaan Observasi ke lapangan selama 3 hari, mulai tanggal 28 Februari s/d 1 Maret 2020 Untuk mengetahui kondisi dan kebutuhan Desa Candiwatu sebagai acuan penyusunan proposal PPM. Selain melakukan observasi juga perijinan untuk melaksanakan Pengabdian Pada Masyarakat di Desa Candiwatu Kecamatan Pacet Kabupaten Mojokerto.

b. Identifikasi Permasalahan. Identifikasi permasalahan oleh TIM PPM dosen Program Studi Perencanaan Wilayah dan Kota Universitas PGRI Adi Buana Surabaya di lakukan di Studio Perencanaan wilayah selama 5 hari 
mulai tanggal 9 s/d 13 Maret 2020 untuk merumuskan permasalahan dan menyusun rancangan kebutuhan sebagai solusi permasalahan.

\section{c. Persiapan alat-alat dan bahan}

Pembelian alat dan bahan untuk pelaksanaan PPM dilaksanakan pada tanggal $16-20$ Maret 2020 . Pembuatan alat bekerjasama dengan Laboratorium Teknik Industri untuk membuat produk tempat sampah (Gambar 3) Design bak sampah dan juga penyangganya merupakan design rancangan dari tim PPM dosen program studi PWK Universitas PGRI Adi Buana Surabaya. untuk pelaksanaan program pengabdian kepada masyarakat dengan membeli bak sampah, peralatan kerangka bak sampah, cat dan pemasangan nama pada masing-masing bak sampah (sampah organic dan unorganik).

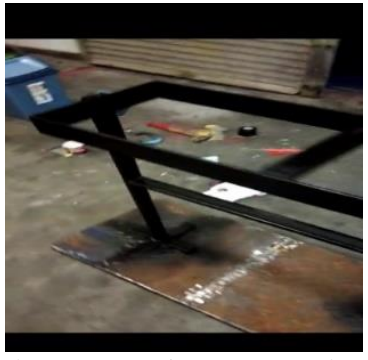

Gambar 3 Persiapan Pembuatan Tempat Sampah

d. Pelaksanaan sosialisasi pemilahan sampah organic dan unorganik di Desa Candiwatu dilaksanakan pada tanggal 07 April 2020.

e. Melakukan evaluasi dan monitoring untuk mengetahui apakah masyarakat telah memahami peran dan manfaat proses pemilahan sampah. Pelaksanaan evaluasi ini dilakukan tanggal 21 April 2020

Untuk lebih jelasnya dapat dilihat pada Gambar 4

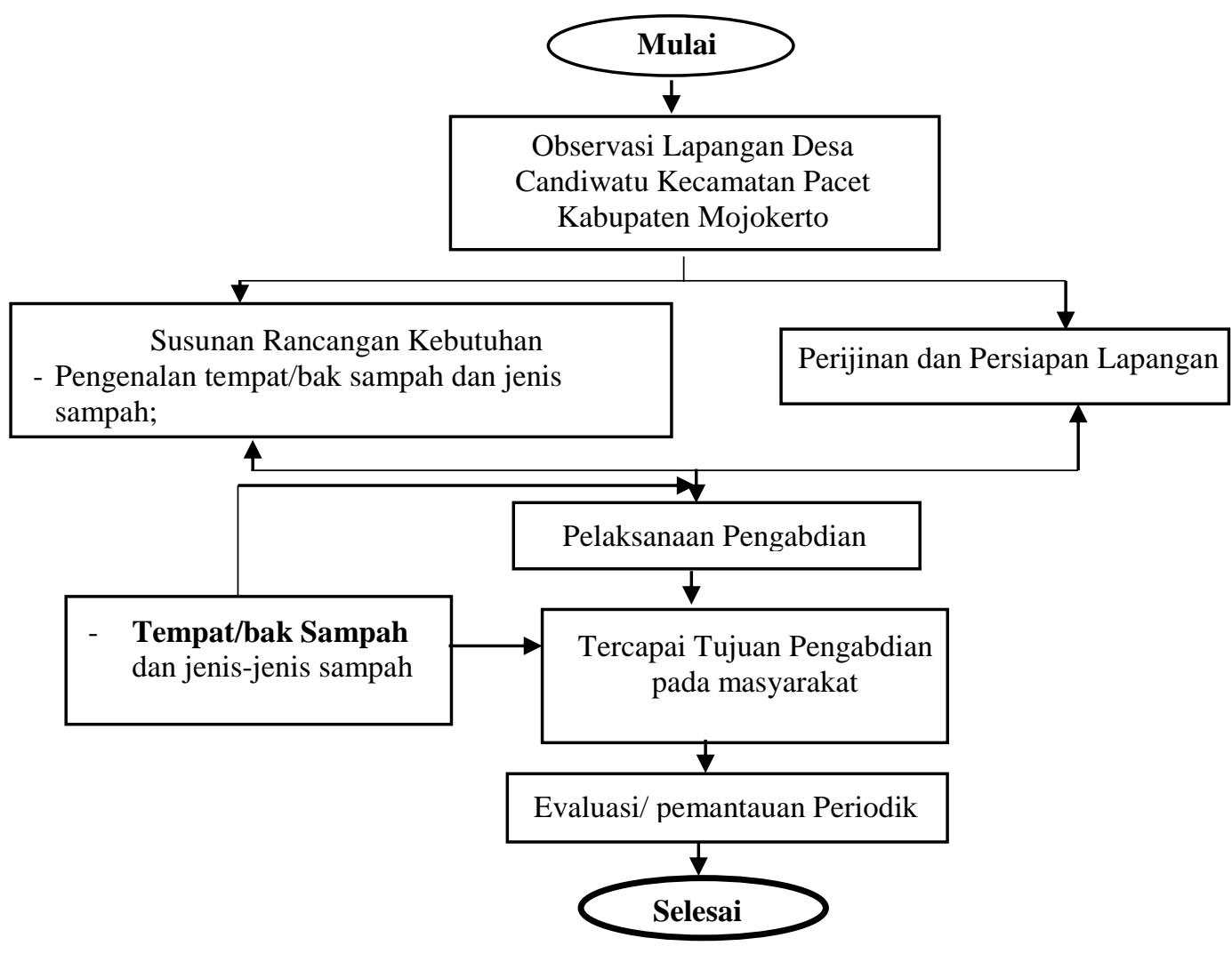

Gambar 4 Skema Pelaksanan Pengabdian Kepada Masyarakat 


\section{HASIL DAN PEMBAHASAN}

Pelaksanaan program PKM dilakukan di kantor Desa Candiwatu Kecamatan Pacet, Kabupaten Mojokerto. Pelaksanaan program PKM ini dihadiri oleh apparat desa, karang taruna dan masyarakat lokal yang ada di Desa Candiwatu dengan total peserta sebanyak 38 orang. Kegiatan ini diawali dengan pembagian pre test kepada peserta guna mengetahui sejauh mana masyarakat melakukan pemilahan sampah. Setelah melakukan pre test maka dilanjutkan dengan proses sosialisasi dan yang terakhir dilakukan post test. Berikut hasil pre tes dapat dilihat pada Gambar 5

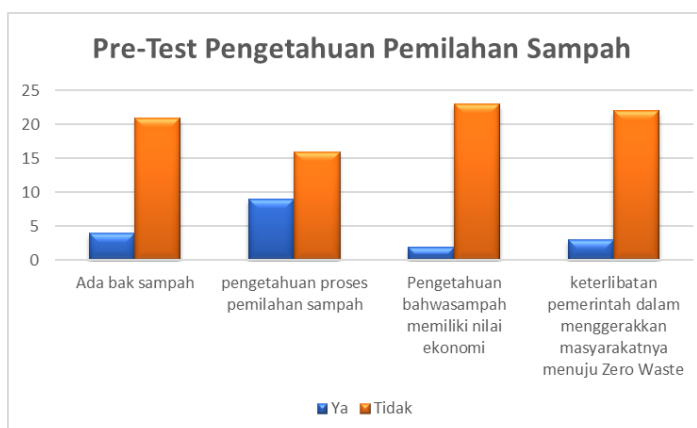

Gambar 5. Hasil Pre-Test Pengetahuan

Peserta tentang Pemilahan Sampah

Gambar 5 hasil pre test menyebutkan bahwa terdapat $85 \%$ masyarakat belum mengetahui tentang proses pemilahan sampah. Artinya masyarakat di Desa Candiwatu lebih dari $50 \%$ belum memiliki informasi bagaimana melakukan pemilahan sampah. Hal ini selaras dengan (Harun, 2017) bahwa meskipun sesorang memiliki sikap peduli terhadap lingkungannya, namun ketidakadaan informasi dapat menyebabkan orang untuk tidak bertindak. Hal ini juga di dukung dengan minimnya ketersediaan bak sampah. Hasil kuesioner menyebutkan bahwa 84\% masyarakatnya tidak memiliki bak sampah di depan rumahnya. Masyarakat masih menggunakan cara tradisional, yaitu dengan membakar sampah. Disamping itu pengetahuan masyarakat mengenai pemanfaatan sisa sampah yang memiliki nilai ekonomis masih minim yaitu hanya $8 \%$. Selain itu di dukung dengan kurangnya sosialisasi pemerintah mengenai zero waste dengan presentase sebesar $12 \%$.
Materi yang disampaikan dalam sosialisasi pelaksanaan pengabdian kepada masyarakat yaitu:

1. Proses memodifikasi tempat sampah berdasarkan kategorinya seperti sampah organik dan unorganik. Dibutuhkan peran masyarakat khususnya ibu-ibu rumah tangga dalam melakukan pemilahan sampah pada masing-masing rumah (Yudhistirani, Syaufina, \& Mulatsih, 2016)

2. Menjelaskan aturan dan kebijakan terkait dengan pengelolaan sampah yang tertuang dalam UU No 18 Tahun 2008

3. Melakukan praktek proses pemilahan sampah

pengabdian kepada masyarakat Metode yang dilakukan pada pelaksanaan pengabdian kepada masyarakat dengan metode sharing atau diskusi (Gambar 6).

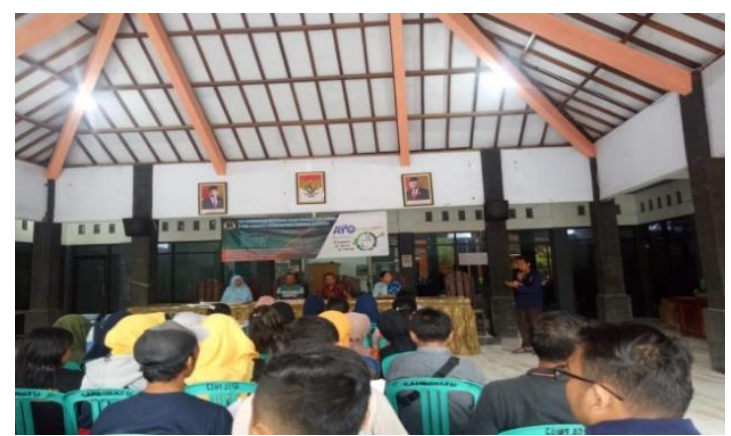

Gambar 6 Sharing dan diskusi saat Pelaksaan Pengabdian Masyarakat

Hasil dari pelaksanaan pengabdian kepada masyarakat setelah dilakukan sosialisasi yaitu (Gambar 7)

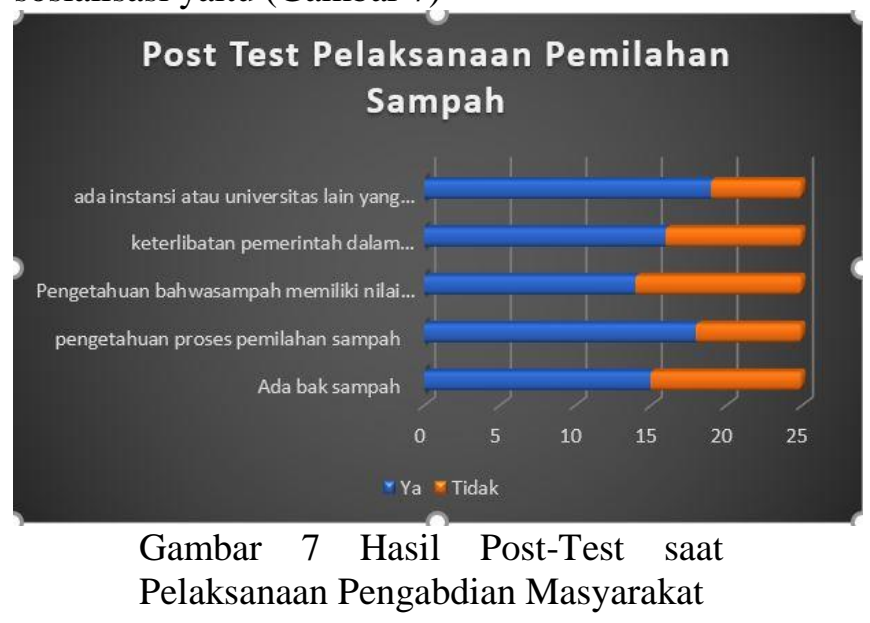

Berdasarkan hasil analisis bahwa pengetahun masyarakat pasca diadakan sosialisasi 
pemilahan sampah (Gambar 8) sebesar mengalami peningkatan yaitu sebesar $72 \%$ karena masyarakatnya mengetahui bahwa sampah yang tidak digunakan lagi bisa bernilai ekonomis, salah satunya yaitu pembuatan kompos (Yunik'ati, Imam, Hariyadi, \& Choirotin, 2019); (Sahwan, 2010). Hal ini dibuktikan sebanyak 56\% peserta sudah mengetahui manfaat daur ulang sampah. Selain itu pemerintah juga mulai bergerak dan membantu dalam melakukan sosialisasi khususnya terkait zero waste sebesar $64 \%$. Bukti nyata dari kegiatan sosialisasi ini yaitu masyarakat yang memiliki tempat sampah sebanyak $60 \%$.

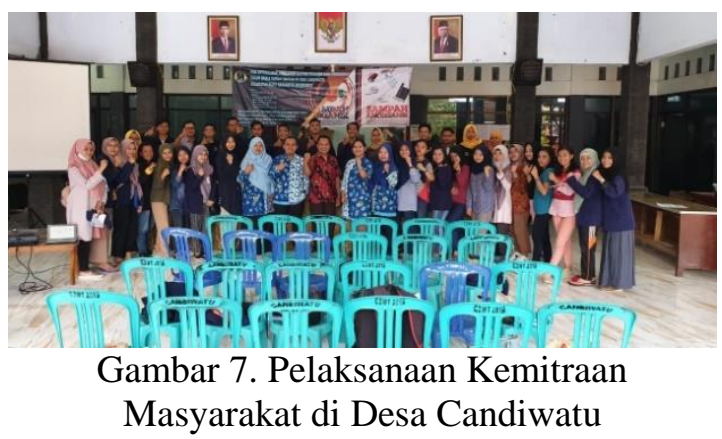

\section{KESIMPULAN}

Kegiatan pelaksanaan pengabdian kepada masyarakat ini telah diikuti oleh 38 orang masyarakat di Desa Candiwatu. Pelaksanaan kegiatan ini dilakukan mulai pukul 09.0011.00 WIB. Kegiatan sosialisasi ini berisi tentang materi pemilahan sampah. Masyarakat di Desa Candiwatu sangat antusias dalam melakukan praktik pemilahan sampah. Diharapkan adanya kegiatan sosialisasi ini masyarakat memiliki tempat sampah berdasarkan kategorinya, yaitu organik dan unorganik.

\section{REFERENSI}

Andina, E. (2019). The Analysis of Waste Sorting Behavior in Surabaya. Jurnal Aspirasi, 10(2), 119-138. https://doi.org/10.22212/aspirasi.v10i2.1 424

Harun, H. (2017). Gambaran Pengetahuan dan Perilaku Masyarakat Dalam Proses Pemilahan Sampah Rumah Tangga Di Desa Hegarmanah. Jurnal Aplikasi Ipteks Untuk Masyarakat, 6(2), 86-88. Retrieved

from http://journal.unpad.ac.id/dharmakarya/a rticle/view/14789/7890

Krisnani, H., Humaedi, S., Ferdryansyah, M., \& Asiah, Dessy Hasanah Siti Asiah, Gigin G Kamil Basar, Sri Sulastri, N. M. (2017). Perubahan Pola Pikir Masyarakat Mengenai Sampah Melalui Pengolahan Sampah Organik Dan Non Organik Di Desa Genteng, Kecamatan Sukasari, Kab. Sumedang. Prosiding Penelitian Dan Pengabdian Kepada Masyarakat, 4(2), 281-289. https://doi.org/10.24198/jppm.v4i2.1434 5

Latifatul, F. N., A, A., A, A., \& Nur, K. R. M. (2018). Pengaruh Sosialisasi Pemilahan Sampah Organik Dan Non Organik Serta Manajemen Sampah Terhadap Penurunan Volume Sampah Di Dusun Krajan Desa Kemuningsari Lor Kecamatan Panti Kabupaten Jember. The Indonesian Journal of Health Science, (September), 84. https://doi.org/10.32528/ijhs.v0i0.1529

Pambudi, Y. S., \& Sudaryantiningsih, C. (2017). Analisis Pengaruh Pengetahuan Dan Sikap Tentang Pengelolaan Sampah Terhadap Perilaku Warga Dalam Mengelola Sampah Rumah Tangga Di Kelurahan Sewu, Kecamatan Jebres, Kota Surakarta. Jurnal Kesehatan Kusuma Husada, 101-108. https://doi.org/10.34035/jk.v8i2.226

Sahwan, F. L. (2010). Kualitas Produk Kompos dan Karakteristik Proses Pengomposan Sampah Kota Tanpa Pemilahan Awal. Jurnal Teknik Lingkungan, 11(1), 79-85.

Sanusi, I., Cahyadi, H., Respati, R., Program, A., Teknik, S., Universitas, S., ... Palangkaraya, M. (2016). Media Ilmiah Teknik Lingkungan Volume 1, Nomor 1, Februari 2016. Jurnal Ilmiah Teknik Lingkungan, 1(1), 42-44.

Utami, B. D., Indrasti, N. S., \& Dharmawan, A. H. (2008). Pengelolaan Sampah Rumahtangga Berbasis Komunitas: Teladan dari Dua Komunitas di Sleman dan Jakarta Selatan. 2(1), 49-68. https://doi.org/10.22500/sodality.v2i1.5 893 
Yudhistirani, S. A., Syaufina, L., \& Mulatsih, S. (2016). Desain Sistem Pengelolaan Sampah Melalui Pemilahan Sampah Organik Dan Anorganik Berdasarkan Persepsi Ibu - Ibu Rumah Tangga. Jurnal Konversi, 4(2), 29. https://doi.org/10.24853/konversi.4.2.29 $-42$

Yunik'ati, Y., Imam, R. M., Hariyadi, F., \& Choirotin, I. (2019). Sadar Pilah Sampah Dengan Konsep 4R (Reduce, Reuse, Recycle, Replace) Di Desa Gedongarum, Kanor, Bojonegoro. JIPEMAS: Jurnal Inovasi Hasil Pengabdian Masyarakat, 2(2), 81. https://doi.org/10.33474/jipemas.v2i2.11 22 